\title{
Stem cell research bravely limps ahead
}

\begin{abstract}
As the US federal government refuses to fund research on human embryonic stem cells and therapeutic cloning, several states are trying to fill the void. Although their efforts are commendable, the budgets of most state programs are small, and a piecemeal and locally constrained approach cannot make up for the lack of federal funding.
\end{abstract}

L ast month US President George W. Bush used his first veto to quash progress in stem cell research. He vetoed a bill that would have allowed the National Institutes of Health (NIH) to fund research on 'surplus' embryos slated for destruction at fertility clinics. The legislature could not muster enough votes to override the veto, so the bill is now dead, but the hopes of scientists and patients are still alive. Human embryonic stem cell research clearly has broad support both in the population and in the government, so it seems unlikely that the blockade will continue once the next president takes office.

The restrictions on federal funding did not begin with Bush's infamous speech in August 2001, which limited human embryonic stem cell research to a few problematic cell lines. A rider forbidding the destruction of human embryos for research purposes, the so-called Dickey Amendment, has been attached to every Health and Human Resources appropriations bill since 1996. (This bill includes funding for the NIH, which underwrites almost all US biomedical research.) However, neither restriction forbids private or state-financed stem cell research. The original isolation of human embryonic stem cells in 1998 was accomplished by US scientists with private funding. In response to federal stonewalling, several states have begun programs to support this research locally.

California was the first state to pass legislation allowing human embryonic stem cell research and therapeutic cloning, in 2002. In November 2004, its voters approved Proposition 71, earmarking $\$ 3$ billion in bonds for stem cell research, to be disbursed over ten years by the newly founded California Institute of Regenerative Medicine (CIRM). The program immediately ran into opposition because of its size and perceived lack of oversight. To date, legal challenges have prevented CIRM from issuing any bonds. Instead the program operates on \$14 million of philanthropic money raised through "bondanticipation notes." This money will either be paid back once bonds are issued or turn into gifts if opponents win the lawsuits. In response to the presidential veto, California's governor authorized another $\$ 150$ million in state loans to initiate the grants. CIRM officials are optimistic that they will win the lawsuits by next summer.

Proposition 71 money will be critical to US stem cell science even if the federal obstruction ends, believes Arnold Kriegstein, who heads the Program in Developmental and Stem Cell Biology at the University of California, San Francisco. In his eyes, the worst thing about the current federal rules is the nightmarish and costly bookkeeping imposed by the need to keep human embryonic stem cell work strictly separate from federally funded projects. To avoid jeopardizing NIH support, researchers have to rent back their own equipment by the hour with non-federal money and meticulously track how much time they spend on this work versus NIH-sponsored work. His university, like other wealthy and dedicated institutions, tries to minimize the conflict by providing privately financed laboratories exclusively for this research. "In this respect, the Senate stem cell bill would have made a huge difference," Kriegstein says.

Other states have joined the effort, though on a much smaller scale. New Jersey authorized human embryonic stem cell research in 2004, after prolonged debate. The first 17 grants (about $\$ 300,000$ each) were awarded in December 2005, and two state universities are launching a new stem cell institute. Connecticut legalized human embryonic stem cell research and committed $\$ 20$ million in 2005, with an annual $\$ 10$ million planned for 10 years. Charles Jennings, a member of the Connecticut Stem Cell Research Advisory Committee (and former Editor of this journal), hopes that grants can be funded by the end of this year. The Illinois governor in 2005 established the Illinois Regenerative Medicine Institute to disburse an initial $\$ 10$ million in grants, which were awarded to 10 laboratories this April. Maryland just endorsed human embryonic stem cell research and committed \$15 million for fiscal year 2007.

In some states, Illinois and Maryland in particular, stem cell research remains controversial and further funding is uncertain. A few states ban human embryonic stem cell research outright. With 'pro-stem cell' and 'pro-embryo' candidates duking it out, the debate makes for marvelous campaign fodder in this year's elections in Michigan, Missouri, Wisconsin and New York. Unsurprisingly, attempts at state funding are stalled under these conditions.

There are good reasons to have almost all science funding administered at the federal rather than the state level. First, meaningful competition for scientific excellence requires a large pool of potential competitors. It seems unlikely that a program like the one in Illinois, for example, which funded 10 projects selected from only 24 local applications, would be able to identify and foster the best science. Naturally, state programs are geared more toward supporting regional academic and business goals than toward enabling scientific progress. Second, a local, piecemeal approach almost inevitably results in wasteful duplication of effort. Third, as the stem cell debate becomes tangled in state election campaigns, candidates may fall for the temptation of promising miracles that scientists cannot deliver-setting up the programs for public disappointment and backlash.

In any case, apart from California's potentially extravagant generosity, the current state efforts are small cash—though much appreciated, in the end they cannot be more than political statements and stopgap measures until the federal government comes to its senses. For all these reasons, we strongly support competitive federal funding for human stem cell research. We hope that turning political tides in Washington will soon make the states' efforts unnecessary. 